\title{
Emerging technologies for the rapid detection of enteric viruses in the aquatic environment
}

Farkas, Kata; Mannion, Finn; Hillary, Luke; Malham, Shelagh; Walker, David

\section{Current Opinion in Environmental Science \& Health}

DOI:

10.1016/j.coesh.2020.01.007

Published: 01/08/2020

Version created as part of publication process; publisher's layout; not normally made publicly available

Cyswllt i'r cyhoeddiad / Link to publication

Dyfyniad o'r fersiwn a gyhoeddwyd / Citation for published version (APA):

Farkas, K., Mannion, F., Hillary, L., Malham, S., \& Walker, D. (2020). Emerging technologies for the rapid detection of enteric viruses in the aquatic environment. Current Opinion in

Environmental Science \& Health, 16, 1-6. https://doi.org/10.1016/j.coesh.2020.01.007

\section{Hawliau Cyffredinol / General rights}

Copyright and moral rights for the publications made accessible in the public portal are retained by the authors and/or other copyright owners and it is a condition of accessing publications that users recognise and abide by the legal requirements associated with these rights. study or research

- Users may download and print one copy of any publication from the public portal for the purpose of private

- You may not further distribute the material or use it for any profit-making activity or commercial gain

- You may freely distribute the URL identifying the publication in the public portal ?

Take down policy

If you believe that this document breaches copyright please contact us providing details, and we will remove access to the work immediately and investigate your claim. 


\section{Journal Pre-proof}

Emerging technologies for the rapid detection of enteric viruses in the aquatic environment

Kata Farkas, Finn Mannion, Luke S. Hillary, Shelagh K. Malham, David I. Walker

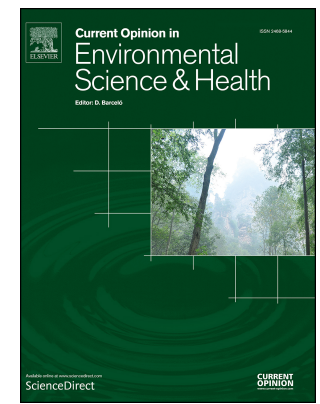

PII: S2468-5844(20)30008-8

DOI: https://doi.org/10.1016/j.coesh.2020.01.007

Reference: COESH 165

To appear in: Current Opinion in Environmental Science \& Health

Received Date: 12 December 2019

Revised Date: 27 January 2020

Accepted Date: 31 January 2020

Please cite this article as: Farkas K, Mannion F, Hillary LS, Malham SK, Walker DI, Emerging technologies for the rapid detection of enteric viruses in the aquatic environment, Current Opinion in Environmental Science \& Health, https://doi.org/10.1016/j.coesh.2020.01.007.

This is a PDF file of an article that has undergone enhancements after acceptance, such as the addition of a cover page and metadata, and formatting for readability, but it is not yet the definitive version of record. This version will undergo additional copyediting, typesetting and review before it is published in its final form, but we are providing this version to give early visibility of the article. Please note that, during the production process, errors may be discovered which could affect the content, and all legal disclaimers that apply to the journal pertain.

Crown Copyright $\odot 2020$ Published by Elsevier B.V. All rights reserved. 


\section{Detection of enteric viruses (i) 0 in the aquatic environment}

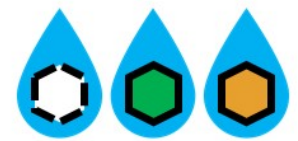

Molecular Techniques
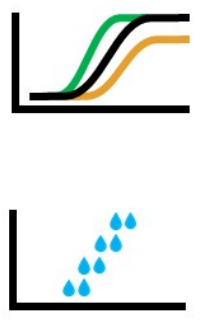

ddPCR

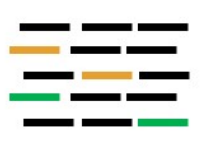

qPCR

Viromics
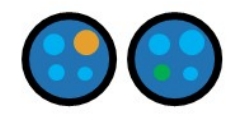

Culturing

Capsid

Integrity

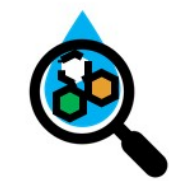

Infectivity/ Integrity

Emerging Technologies

Biosensors

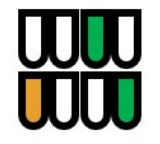

Isothermal

Amplification

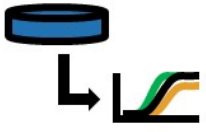

每

Long Read Sequencing 
1 Emerging technologies for the rapid detection of enteric viruses in the

2 aquatic environment

3

4 Kata Farkas $^{1 *}$, Finn Mannion ${ }^{1}$, Luke S. Hillary ${ }^{2}$, Shelagh K. Malham ${ }^{1}$, David I. Walker ${ }^{3}$

$5{ }^{1}$ School of Ocean Sciences, Bangor University, Menai Bridge, Anglesey, UK

$6{ }^{2}$ School of Natural Sciences, Bangor University, Deiniol Road, Bangor, Gwynedd, UK

$7 \quad{ }^{3}$ Centre for Environment, Fisheries and Aquaculture Science, Weymouth, Dorset, UK

8

$9 \quad *$ Corresponding author: Kata Farkas

10

ORCID: 0000-0002-7068-3228

11

+441248382615

12

fkata211@gmail.com 


\section{Abstract}

14 Due to the high diversity of enteric viruses in the environment, there is an increasing need for 15 methods enabling the multiple detection of different pathogens. Quantitative, emerging digital PCR and isothermal amplification approaches are capable of the quantification of multiple targets, and

17 hence are suitable for long-term monitoring and source tracking of enteric viruses in the aquatic environment. The combination of culturing with PCR-based detection enables rapid viral risk assessment, especially with host tissues capable of the propagation of several viral strains. Viability assays may provide a better understanding on viral survival than PCR-based approaches alone, however, the usefulness of these assays in wastewater and environmental water samples should be further investigated. Undoubtedly, emerging sequencing-based technologies provide invaluable data on the ecology and diversity of viruses, and, along with rapid on-site technologies, e.g. biosensors, may be implemented in viral risk assessment in the aquatic environment in the near future. 
27

\section{Introduction}

Enteric viruses are the major cause of gastroenteritis globally. They enter the aquatic environment via wastewater discharge, agricultural activities and landfill run-off polluting surface water, groundwater and sediment. Due to their extreme persistency, they contaminate recreational waters, drinking water sources, irrigation water and they are accumulated by shellfish. Hence, they are often responsible for water- and foodborne illnesses [1]. There are over 150 pathogenic viruses that may be found in water environments, including noroviruses, sapoviruses, hepatitis A/E viruses, rotaviruses, enteroviruses, Aichi viruses, astroviruses, adenoviruses and polyomaviruses [1]. Hence, there is a need for the simultaneous detection of multiple strains or species to better understand viral risks. The quantification process of viruses involves the concentration of environmental samples prior to detection, which results in a difficult matrix that hinders accurate detection [2]. This review focuses on recent method developments (Table 1) for the accurate detection of multiple viral targets which have been used, or may be used, for enteric viral monitoring in the aquatic environment.

\section{Detection and quantification of viral nucleic acids}

\section{$2.1 \mathrm{q}(\mathrm{RT}$-)PCR and $\mathrm{d}(\mathrm{RT}$ T-)PCR}

Polymerase chain reaction (PCR) methods targeting genes of pathogens have been widely used in environmental health research. The most common method in monitoring viruses is the real-time or quantitative PCR (qPCR) often combined with a reverse transcription step (RT-qPCR) to quantify RNA targets. The PCR reaction can be performed on a microfluidic platform, reducing the time and costs of the assay. Microfluidic qPCR have been used for the detection of multiple viral targets in water samples [3]. However, as small volumes of amplification reaction mixes and samples are used, the limit of detection can be high (e.g. 150 copies/ $\mu$ ) [3], which is not ideal for most environmental samples. 
The emerging technology for viral quantification is the digital (RT-)PCR (d(RT-)PCR), where the PCR mix is dispersed in thousands to millions of individual wells on a chip or water-oil droplets and the target sequence quantities are calculated based on +/- signals. Quantitative/dPCR approaches are rapid and highly sensitive, enabling the strain-level detection of 1-10 genome copies (gc) within 1-4 hours. The major advantage of dPCR over qPCR is that it performs absolute quantification and hence no standards are required. Comparative studies showed that $\mathrm{dPCR}$ is more sensitive and less affected by inhibitors than qPCR-based approaches $[4,5]$. However, $d(R T-) P C R$ has a narrower range of quantification than qPCR [5], and hence samples with high viral concentrations (e.g. wastewater samples) should be diluted prior to d(RT-)PCR for quantification.

TaqMan (probe-based) qPCR assays can be multiplexed enabling the parallel detection of 2-4 targets within one qPCR reaction well [6-8]. This can be useful for the simultaneous quantification of human and animal viruses for source tracking [9]. Multiplex qPCR assays are also available commercially and have been used to identify viral pathogens in stool samples [10]. Digital PCR assays can also be multiplexed, and a duplex assay has been used for viral detection in clinical setting [11]. The main disadvantage of the d(RT-)PCR is the high costs (either equipment - droplet dPCR or consumables chip-based dPCR), which obstruct the wide use of the equipment in environmental research and routine monitoring.

\subsection{Isothermal amplification}

Isothermal amplification methods, such as nucleic acid sequence-based amplification (NASBA), recombinase polymerase amplification (RPA), helicase dependent amplification, and loop-mediated isothermal amplification (LAMP), have the potential to detect low concentration of target DNA or RNA sequences within $15-60$ minutes at $37-65^{\circ} \mathrm{C}$. These techniques have been used for pathogen detection in environmental samples [12], with RPA, LAMP and NASBA have been used for viral targets [13-15]. 
LAMP uses three primer sets which enables the creation of loop sequences and increases the number of primer binding sites with each amplification. Therefore, LAMP is highly specific and produces considerably more amplicons than PCR within a short period of time without using a thermal cycler. An RT step can easily be implemented for the detection of RNA target and it can also be multiplexed [16]. LAMP is less sensitive to inhibitors compared to PCR [13]. Due to its simplicity, specificity and reliability, LAMP could be implemented in viral water quality assessment. A microfluidic approach has also been used on water samples to detect multiple cellular pathogen targets [17], but not for viruses.

NASBA and RPA uses a combination of enzymes to rapidly amplify multiple target nucleic acid sequences. Unlike other nucleic acid amplification methods, NASBA can directly amplify from an RNA target, removing the need for an RT step. However, due to the complexity of the RPA and NASBA reactions, they may be more prone to inhibition than other techniques and can generate unreliable results $[14,15,18]$. More research is needed to assess the usefulness of RPA in environmental virus monitoring. A recent review suggested that NASBA has potential for further application for environmental analysis [19]. However, the difficulties in generating reliable, quantitative results and the current cost of NASBA relative to PCR and LAMP limit its adoption as a common tool for analysis of viruses in the environment [18].

\subsection{High-throughput sequencing}

High-throughput sequencing (HTS) can be used to survey the DNA and/or RNA of viral communities in aquatic systems without the bias of pre-selecting which viruses to detect. In this way, HTS of environmental water samples can be used to identify emergent viruses as well as known pathogens [20]. The recovery of whole genomes of uncultured viruses from metagenomics data can yield genotype-level identification and aid the design of qPCR assays for finer scale surveying $[21,22]$. HTS can also inform targeted amplicon sequencing studies that examine specific viral groups and yield finer resolution of their geographic distribution [23] and diversity [24]. 
Nonetheless, qPCR and HTS can sometimes produce conflicting evidence on the presence of specific viruses [25] and data-processing can introduce artefacts and chimeric sequences [26]. Long-read

101 sequencing (PacBio, Oxford Nanopore) can overcome some of these limitations but it produces high error rates of up to $15 \%[27,28]$. The major disadvantages of HTS are the costs of sequencing and the time required for bioinformatics analysis, which prohibits the use of these advanced technologies for routine monitoring.

\section{Assessment of viral infectivity}

The main disadvantage of all nucleic acid detection systems is the lack of information on infectivity. The culturing of human viruses requires specific equipment (e.g. $\mathrm{CO}_{2}$ incubator, inverted microscope) and well-maintained cell lines, and is therefore rarely used in routine viral monitoring. Furthermore, in vitro culturing assays are not available for many human viruses and the existing methods based on the observation of cell lysis due to viral infection (i.e. cytopathic effect; CPE) may take weeks. Nonetheless, those methods have the capability to assess viral infectivity and that is crucial to understand the removal of viruses during wastewater treatment and the decay of viruses in the environment. Therefore, attempts have been made to simplify and accelerate viral culturing techniques.

Integrated cell culture (ICC) (RT-)qPCR have been used to reduce the time of culturing necessary for infectious virus detection to 1-4 days, as the increase in viral DNA/RNA levels due to viral propagation can be accurately detected by (RT-)qPCR several days before CPE is visible. Recently, these techniques have been used for the detection of enteric viruses in surface water $[29,30]$. The assay can be further shortened to a few hours by detecting viruses at the early stage of cell attachment [31]. The advantage of ICC-(RT-)qPCR is that one cell line can be used for the propagation of several different viral strains enabling the assessment of different targets in water samples $[29,32]$. 
The focus of research on viral culturing has been the propagation of human noroviruses. Since 2016, three methods have been developed using human B cells [33], human stem cell-derived enteroids [34] and intestinal epithelial cells [35] and zebrafish embryos [36] as hosts. All methods have been shown to result in norovirus gc increase within 2-4 days. However, these methods have rarely been used to investigate norovirus infectivity in environmental samples and their usefulness to propagate different viruses needs to be investigated.

\section{Assessment of viral integrity}

Due to the disadvantages of RNA/DNA and culturing-based viral detection systems, inexpensive and simple assays evaluating the integrity of the viral particles have been developed, based on the assumption that an intact virus particle is infectious.

\subsection{Elimination of free viral nucleic acids}

Free nucleic acids can be eliminated by enzymatic (RNase or DNase) treatment, during which the non-encapsidated viral nucleic acids are degraded, prior to PCR-based quantification. Enzymatic treatments have been shown to eliminate free nucleic acids to some extent [37]. The treatment is often coupled with proteinase $\mathrm{K}$ treatment, which degrades the damaged capsid proteins, enabling the nucleases to reach nucleic acids from non-infectious viral particles. However, proteinase $\mathrm{K}$ treatment has been shown to damage infectious viral particles as well, hence it should be used with caution [38].

Another approach for the elimination of free nucleic acids is viability treatment using intercalating dyes. These substances are able to penetrate compromised viral capsids and, when the sample is exposed to light, it covalently binds to nucleic acids preventing PCR amplification. The most frequently used dyes in environmental studies are propidium monoazide (PMA) and ethidium monoazide (EMA). Other viability treatments use substances that bind to nucleic acids without light exposure, such as platinum chloride $\left(\mathrm{PtCl}_{4}\right)$ and cis-dichlorodiammineplatinum (CDDP), which have 
also been tested on heat/UV inactivated or chlorinated viral samples. The results suggest that these treatments eliminate the majority of free nucleic acids, however, their performance shows variations amongst different sample types and viral species [39-42]. PMA treatment can also been enhanced by the addition of surfactants $[39,41,43,44]$ or by combination with EMA [45]. The major advantage of these assays is that they are not strain specific and hence, multiple targets can be analysed in one sample.

\subsection{Capsid integrity assay}

Capsid integrity assays are based on affinity binding between a protein and the viral capsid. As the capsid proteins show great variations, one assay is only suitable for a few strains or species belonging to the same family. Most research has been focusing on the capsid integrity of noroviruses, mainly genotype II, assessed using histo-blood group antigens (HBGA), including porcine gastric mucin (PGM). These proteins can be immobilised to plate wells or magnetic beads [46]. When the sample is added, viral particles bind to the proteins and the subsequent washing steps can eliminate free viral nucleic acids and inhibitors, which would affect PCR-based detection. This approach is very easy and rapid and can be applied in any laboratories, however, it may not eliminate all damaged, and hence non-infectious viruses after heat-inactivation and UV treatment [47] and seems to be less effective on norovirus genogroup I viruses than on genogroup II [48].

\section{Biosensors}

Biosensors transduce biological responses to measurable signals upon interaction with their target [49]. Aptamer-based biosensors (aptasensors) hold single-stranded DNA or RNA oligonucleotides (i.e. aptamers), which have the ability to bind to target DNA or proteins with high specificity and affinity, and produce a measurable signal upon binding. Aptasensors developed for norovirus detection based on electrochemical, fluorescence, colorimetric and surface plasmon resonance detection platforms [50-52] may be the most promising biosensor for viral detection in aquatic samples. Aptasensors are generally resistant to environmental inhibitors, enabling high recoveries 
and low detection limits within minutes [53]. Some aptamers have the potential for the multiple detection of different norovirus strains [54]. Broadly reactive aptamers combined with biosensor technologies could provide a valuable asset for the simultaneous detection of enteric viruses in the aquatic environment.

\section{Conclusion}

Various methods are available for the detection of viral pathogens in the environment, however, all of them have their limitations. For rapid assessment and source tracking, PCR and isothermal amplification approaches should be used. To estimate viral persistence, culturing-based methods and virus particle integrity assays can be used, however, more comparative studies (integrity vs. infectivity) are needed for the validation of these approaches in environmental risk assessment. Amplicon and full genome sequencing, however expensive and time consuming, can detect novel and emerging viral species and strains and hence is helpful in initial risk assessment and to understand the local and global distribution of viruses for epidemiological investigations. Lab-onchip LAMP assays and biosensors, have the capacity to detect and quantify target viruses on site within an hour. With further development, these assays could be used for environmental monitoring of common enteric virus strains, providing an invaluable tool for authorities and other stakeholders for the rapid initial water/food quality assessment and mitigation.

\section{Acknowledgements}

KF was supported by the Shellfish Centre RD\&I operation, part-funded by the EU's West Wales and the Valleys European Regional Development Fund (ERDF) Operational Programme through the Welsh Government. LSH was supported by a Soils Training and Research Studentship (STARS) grant from the Biotechnology and Biological Sciences Research Council (BBSRC) and Natural Environment Research Council (NERC) [NE/M009106/1]. FM was supported by the Developing Assurance Scheme for Shellfish and Human Health (DASSHH) part funded by Seafish. 


\begin{tabular}{|c|c|c|c|c|}
\hline Method & Target & Quantification & Sensitivity & $\begin{array}{l}\text { Time to } \\
\text { complete }\end{array}$ \\
\hline$q(R T-) P C R$ & Up to 4 viral strains/species & $\begin{array}{l}\text { Relative } \\
\text { quantification }\end{array}$ & $\begin{array}{l}1-10 \mathrm{gc} / \text { reaction } \\
{[5,7]}\end{array}$ & 1-4 hours \\
\hline$d(R T-) P C R$ & Up to 2 viral strains/species & $\begin{array}{l}\text { Absolute } \\
\text { quantification }\end{array}$ & $\begin{array}{l}1-10 \mathrm{gc} / \text { reaction } \\
{[5]}\end{array}$ & $1-3$ hours \\
\hline LAMP & Up to 2 viral strains/species & $\begin{array}{l}\text { Absolute } \\
\text { quantification }\end{array}$ & $2 \mathrm{PFU} / \mathrm{ml}[12]$ & $15-60 \mathrm{~min}$ \\
\hline RPA & Up to 4 viral strains/species & Non-quantitative & $\begin{array}{l}50 \mathrm{gc} / \text { reaction } \\
{[15]}\end{array}$ & $20 \mathrm{~min}$ \\
\hline HTS & $\begin{array}{l}\text { Non-targeted detection of } \\
\text { any RNA or DNA viruses }\end{array}$ & Semi-quantitative* & $N / A$ & 1 week \\
\hline Culturing & $\begin{array}{l}\text { Non-targeted detection of } \\
\text { viruses can be cultured in } \\
\text { the host cell }\end{array}$ & $\begin{array}{l}\text { Absolute } \\
\text { quantification }\end{array}$ & $\begin{array}{l}1 \mathrm{TCID} 50 / \mathrm{ml} \\
{[31]}\end{array}$ & 1-2 weeks \\
\hline ICC-q(RT-)PCR & As $q(R T-) P C R$ & As $q(R T-) P C R$ & $\begin{array}{l}0.02-0.2 \\
\mathrm{TCID} 50 / \mathrm{ml}[31]\end{array}$ & 1-4 days \\
\hline Viability assay & $\begin{array}{l}\text { Eliminates all free nucleic } \\
\text { acids }\end{array}$ & $\begin{array}{l}\text { Depends on } \\
\text { detection method }\end{array}$ & $\begin{array}{l}\text { Depends on } \\
\text { detection } \\
\text { method }\end{array}$ & $\begin{array}{l}1 \text { hour + } \\
\text { detection }\end{array}$ \\
\hline $\begin{array}{l}\text { Capsid } \\
\text { integrity assay }\end{array}$ & $\begin{array}{l}\text { Accumulates closely related } \\
\text { viral strains }\end{array}$ & $\begin{array}{l}\text { Depends on } \\
\text { detection method }\end{array}$ & $\begin{array}{l}\text { Depends on } \\
\text { detection } \\
\text { method }\end{array}$ & $\begin{array}{l}1 \text { hour + } \\
\text { detection }\end{array}$ \\
\hline Aptasensors & $\begin{array}{l}\text { Accumulates closely related } \\
\text { viral strains }\end{array}$ & $\begin{array}{l}\text { Relative } \\
\text { quantification }\end{array}$ & $\begin{array}{l}200 \text { virus } / \mathrm{ml} \\
{[51]}\end{array}$ & $10 \mathrm{~min}$ \\
\hline
\end{tabular}

*HTS may enable relative abundance quantification based on the relative proportion of contigs, however, its performance is highly dependent on sample preparation and bioinformatics analysis [26]. 
206

207

* of special interest

** of outstanding interest

1. Radin D: New trends in food-and waterborne viral outbreaks. Arch Biol Sci 2014, 66:1-9.

2. Haramoto E, Kitajima M, Hata A, Torrey JR, Masago Y, Sano D, Katayama H: A review on recent progress in the detection methods and prevalence of human enteric viruses in water. Water Res 2018, 135:168-186.

3. Ishii S, Kitamura G, Segawa T, Kobayashi A, Miura T, Sano D, Okabe S: Microfluidic Quantitative PCR for Simultaneous Quantification of Multiple Viruses in Environmental Water Samples. Appl Environ Microbiol 2014, 80:7505 LP - 7511.

4. Jahne MA, Brinkman NE, Keely SP, Zimmerman BD, Wheaton EA, Garland JL: Droplet digital PCR quantification of norovirus and adenovirus in decentralized wastewater and graywater collections: Implications for onsite reuse. Water Res 2020, 169:115213.

5. Sui Z, Liu S, Liu S, Wang J, Xue L, Liu X, Wang B, Gu S, Wang Y: Evaluation of digital PCR for absolute and accurate quantification of Hepatitis A virus. In 2019 International Conference on Biomedical Sciences and Information Systems. . 2019:9.

6. Ahmed W, Payyappat S, Cassidy M, Besley C: A duplex PCR assay for the simultaneous quantification of Bacteroides HF183 and crAssphage CPQ_056 marker genes in untreated sewage and stormwater. Environ Int 2019, 126:252-259.

7. Farkas K, Malham SK, Peters DE, de Rougemont A, McDonald JE, de Rougemont A, Malham SK, Jones DL: Evaluation of two triplex one-step qRT-PCR assays for the quantification of human enteric viruses in environmental samples. Food Environ Virol 2017, 9:343-349.

8. Huang X, Chen J, Yao G, Guo Q, Wang J, Liu G: A TaqMan-probe-based multiplex real-time RTqPCR for simultaneous detection of porcine enteric coronaviruses. Appl Microbiol Biotechnol 2019, 103:4943-4952.

9. Bortagaray V, Lizasoain A, Piccini C, Gillman L, Berois M, Pou S, Díaz M del P, Tort FL, Colina R, Victoria M: Microbial Source Tracking Analysis Using Viral Indicators in Santa Lucía and Uruguay Rivers, Uruguay. Food Environ Virol 2019, doi:10.1007/s12560-019-09384-2.

10. Hirvonen JJ: Comparison of three multiplex real-time PCR assays for detection of enteric viruses in patients with diarrhea. Eur J Clin Microbiol Infect Dis 2019, 38:241-244.

11. Yurick D, Khoury G, Clemens B, Loh L, Pham H, Kedzierska K, Einsiedel L, Purcell D: Multiplex Droplet Digital PCR Assay for Quantification of Human T-Cell Leukemia Virus Type 1 Subtype c DNA Proviral Load and T Cells from Blood and Respiratory Exudates Sampled in a Remote Setting. J Clin Microbiol 2019, 57:e01063-18.

12. Zhang $\mathrm{H}, \mathrm{Xu} \mathrm{Y}$, Fohlerova Z, Chang H, lliescu C, Neuzil P: LAMP-on-a-chip: Revising microfluidic platforms for loop-mediated DNA amplification. TrAC Trends Anal Chem 2019, 113:44-53. 
13. Huang X, Lin X, Urmann K, Li L, Xie X, Jiang S, Hoffmann MR: Smartphone-Based in-Gel LoopMediated Isothermal Amplification (gLAMP) System Enables Rapid Coliphage MS2 Quantification in Environmental Waters. Environ Sci Technol 2018, 52:6399-6407.

**Describes the first study using LAMP for the detection of enteric viral surrogate, MS2 phage in water samples. The method is highly specific, sensitive and not affected by amplification inhibitors. The 30-min assay uses immobilized viral particles and fluorescent detection on a smartphone.

14. Rutjes SA, van den Berg HH, Lodder WJ, de Roda Husman AM: Real-time detection of noroviruses in surface water by use of a broadly reactive nucleic acid sequence-based amplification assay. Appl Env Microbiol 2006, 72:5349-5358.

15. Rames EK, Macdonald J: Rapid assessment of viral water quality using a novel recombinase polymerase amplification test for human adenovirus. Appl Microbiol Biotechnol 2019, 103:8115-8125.

16. Zhang J, Borth W, Lin B, Melzer M, Shen H, Pu X, Sun D, Nelson S, Hu J: Multiplex detection of three banana viruses by reverse transcription loop-mediated isothermal amplification (RTLAMP). Trop Plant Pathol 2018, 43:543-551.

17. Liu $Q$, Zhang $X$, Yao Y, Jing W, Liu S, Sui G: A novel microfluidic module for rapid detection of airborne and waterborne pathogens. Sens Actuators B Chem 2018, 258:1138-1145.

18. Walker DI, McQuillan J, Taiwo M, Parks R, Stenton CA, Morgan H, Mowlem MC, Lees DN: A highly specific Escherichia coli qPCR and its comparison with existing methods for environmental waters. Water Res 2017, 126:101-110.

19. Hønsvall BK, Robertson LJ: From research lab to standard environmental analysis tool: Will NASBA make the leap? Water Res 2017, 109:389-397.

20. Adriaenssens EM, Farkas K, Harrison C, Jones DL, Allison HE, McCarthy AJ: Viromic analysis of wastewater input to a river catchment reveals a diverse assemblage of RNA viruses. mSystems 2018, 3:e00025-18.

21. Bibby K, Crank K, Greaves J, Li X, Wu Z, Hamza IA, Stachler E: Metagenomics and the development of viral water quality tools. Npj Clean Water 2019, 2:9.

22. Wang H, Kjellberg I, Sikora P, Rydberg H, Lindh M, Bergstedt O, Norder H: Hepatitis E virus genotype 3 strains and a plethora of other viruses detected in raw and still in tap water. Water Res 2020, 168:115141.

23. Edwards RA, Vega AA, Norman HM, Ohaeri M, Levi K, Dinsdale EA, Cinek O, Aziz RK, McNair K, Barr JJ, et al.: Global phylogeography and ancient evolution of the widespread human gut virus crAssphage. Nat Microbiol 2019, 4:1727-1736.

24. Hata A, Kitajima M, Haramoto E, Lee $S$, Ihara M, Gerba CP, Tanaka H: Next-generation amplicon sequencing identifies genetically diverse human astroviruses, including recombinant strains, in environmental waters. Sci Rep 2018, 8:11837.

*Uses amplicon sequencing to identify and compare novel and emerging Aichi virus strains in wastewater, river water and groundwater collected in Arizona and in Nepal. This approach enabled the distinction of human and animal viruses and the description of seasonality. 
25. Bibby K, Peccia J: Identification of viral pathogen diversity in sewage sludge by metagenome analysis. Environ Sci Technol 2013, 47:1945-1951.

26. Roux S, Emerson JB, Eloe-Fadrosh EA, Sullivan MB: Benchmarking viromics: an in silico evaluation of metagenome-enabled estimates of viral community composition and diversity. PeerJ 2017, 5:e3817.

27. Rang FJ, Kloosterman WP, de Ridder J: From squiggle to basepair: computational approaches for improving nanopore sequencing read accuracy. Genome Biol 2018, 19:90.

28. Rhoads A, Au KF: PacBio sequencing and its applications. Genomics Proteomics Bioinformatics 2015, 13:278-289.

29. Pang X, Qiu Y, Gao T, Zurawell R, Neumann NF, Craik S, Lee BE: Prevalence, levels and seasonal variations of human enteric viruses in six major rivers in Alberta, Canada. Water Res 2019, 153:349-356.

*Describes an ICC-qPCR-based system for the detection of multiplex viral targets using two cell lines (African rhesus/green monkey kidney cells). The targets includes adenovirus, rotavirus, reovirus and enterovirus, however, some river water samples negative with ICC-qPCR produced cythopathic effect.

30. Sedji MI, Varbanov M, Meo M, Colin M, Mathieu L, Bertrand I: Quantification of human adenovirus and norovirus in river water in the north-east of France. Environ Sci Pollut Res 2018, 25:30497-30507.

31. Guo X, Wang S, Zhao C, Li J, Zhong J: An integrated cell absorption process and quantitative PCR assay for the detection of the infectious virus in water. Sci Total Environ 2018, 635:964971.

**Describes and validates a 4-hour, cell adsorption-based infectivity assay for the detection of infectious adenovirus and poliovirus particles after chlorination and in river water samples. The assay is based on the assumption that the virus particles able to attach to the cells are infectious.

32. Ryu H, Schrantz KA, Brinkman NE, Boczek LA: Applicability of integrated cell culture reverse transcriptase quantitative PCR (ICC-RTqPCR) for the simultaneous detection of the four human enteric enterovirus species in disinfection studies. J Virol Methods 2018, 258:35-40.

*Describes a 1-day ICC-RT-qPCR method for the simultaneous detection of infectious coxsackievirus A10, echovirus 30, poliovirus 1 and enterovirus 70 to assess the effect of UV-treatment.

33. Jones MK, Grau KR, Costantini V, Kolawole AO, de Graaf M, Freiden P, Graves CL, Koopmans M, Wallet SM, Tibbetts SA, et al.: Human norovirus culture in B cells. Nat Protoc 2015, 10:19391947.

34. Ettayebi K, Crawford SE, Murakami K, Broughman JR, Karandikar U, Tenge VR, Neill FH, Blutt SE, Zeng X-L, Qu L, et al.: Replication of human noroviruses in stem cell-derived human enteroids. Science 2016, 353:1387-1393.

35. Sato S, Hisaie K, Kurokawa S, Suzuki A, Sakon N, Uchida Y, Yuki Y, Kiyono H: Human Norovirus Propagation in Human Induced Pluripotent Stem Cell-Derived Intestinal Epithelial Cells. Cell Mol Gastroenterol Hepatol 2019, 7:686-688.e5. 
36. Van Dycke J, Ny A, Conceição-Neto N, Maes J, Hosmillo M, Cuvry A, Goodfellow I, Nogueira TC, Verbeken $\mathrm{E}$, Matthijnssens J, et al.: A robust human norovirus replication model in zebrafish larvae. PLoS Pathog 2019, 15:e1008009-e1008009.

37. Leblanc D, Gagné M-J, Poitras É, Brassard J: Persistence of murine norovirus, bovine rotavirus, and hepatitis $A$ virus on stainless steel surfaces, in spring water, and on blueberries. Food Microbiol 2019, 84:103257.

38. Langlet J, Kaas L, Croucher D, Hewitt J: Effect of the Shellfish Proteinase K Digestion Method on Norovirus Capsid Integrity. Food Environ Virol 2018, 10:151-158.

39. Canh VD, Kasuga I, Furumai H, Katayama H: Viability RT-qPCR Combined with Sodium Deoxycholate Pre-treatment for Selective Quantification of Infectious Viruses in Drinking Water Samples. Food Environ Virol 2019, 11:40-51.

*Compares the usefulness of EMA, PMA and CDDP treatment, with and without surfactant, and infectivity (plaque) assay on heat-inactivated Aichi virus and shows that the viability tests with surfactants performs similar to infectivity assay.

40. Leifels M, Shoults D, Wiedemeyer A, Ashbolt NJ, Sozzi E, Hagemeier A, Jurzik L: Capsid Integrity qPCR-An Azo-Dye Based and Culture-Independent Approach to Estimate Adenovirus Infectivity after Disinfection and in the Aquatic Environment. Water 2019, 11:1196.

41. Monteiro S, Santos R: Enzymatic and viability RT-qPCR assays for evaluation of enterovirus, hepatitis A virus and norovirus inactivation: Implications for public health risk assessment. J Appl Microbiol 2018, 124:965-976.

**This work includes a summary table on previous studies evaluating the usefulness of RNase vs PMA-based viability PCR assays. It also highlights the advantages of using a surfactant to enhance the effect of PMA in viability tests.

42. Randazzo W, Vasquez-García A, Aznar R, Sánchez G: Viability RT-qPCR to Distinguish Between HEV and HAV With Intact and Altered Capsids. Front Microbiol 2018, 9:1973.

43. Lee H-W, Lee H-M, Yoon S-R, Kim SH, Ha J-H: Pretreatment with propidium monoazide/sodium lauroyl sarcosinate improves discrimination of infectious waterborne virus by RT-qPCR combined with magnetic separation. Environ Pollut 2018, 233:306-314.

44. Randazzo W, Piqueras J, Rodríguez-Díaz J, Aznar R, Sánchez G: Improving efficiency of viabilityqPCR for selective detection of infectious HAV in food and water samples. J Appl Microbiol 2018, 124:958-964.

45. Gyawali P, Hewitt J: Detection of Infectious Noroviruses from Wastewater and Seawater Using PEMAXTM Treatment Combined with RT-qPCR. Water 2018, 10:841.

46. Tian P, Yang D, Shan L, Li Q, Liu D, Wang D: Estimation of Human Norovirus Infectivity from Environmental Water Samples by In Situ Capture RT-qPCR Method. Food Environ Virol 2018, 10:29-38.

47. Walker DI, Cross LJ, Stapleton TA, Jenkins CL, Lees DN, Lowther JA: Assessment of the Applicability of Capsid-Integrity Assays for Detecting Infectious Norovirus Inactivated by Heat or UV Irradiation. Food Environ Virol 2019, 11:229-237. 
48. Farkas K, Cooper DM, McDonald JE, Malham SK, de Rougemont A, Jones DL, Rougemont A de, Jones DL, de Rougemont A, Jones DL: Seasonal and spatial dynamics of enteric viruses in wastewater and in riverine and estuarine receiving waters. Sci Total Environ 2018, 634:11741183.

49. Neethirajan S, Ahmed SR, Chand R, Buozis J, Nagy É: Recent Advances in Biosensor Development for Foodborne Virus Detection. Nanotheranostics 2017, 1:272-295.

50. Kim S, Lee S, Lee HJ: An aptamer-aptamer sandwich assay with nanorod-enhanced surface plasmon resonance for attomolar concentration of norovirus capsid protein. Sens Actuators $B$ Chem 2018, 273:1029-1036.

51. Shen F, Cheng Y, Xie Y, Yu H, Yao W, Li H-W, Guo Y, Qian H: DNA-silver nanocluster probe for norovirus RNA detection based on changes in secondary structure of nucleic acids. Anal Biochem 2019, 583:113365.

52. Weerathunge $P$, Ramanathan R, Torok VA, Hodgson K, Xu Y, Goodacre R, Behera BK, Bansal V: Ultrasensitive Colorimetric Detection of Murine Norovirus Using NanoZyme Aptasensor. Anal Chem 2019, 91:3270-3276.

**This study uses combined aptamers with the enzyme-mimic catalytic activity of gold nanoparticles to produce a colorimetric assay for the detection of murine norovirus. The sensor produces a blue colour in the presence of noroviruses.

53. Schilling KB, DeGrasse J, Woods JW: The influence of food matrices on aptamer selection by SELEX (systematic evolution of ligands by exponential enrichment) targeting the norovirus $P$ Domain. Food Chem 2018, 258:129-136.

54. Moore MD, Escudero-Abarca BI, Suh SH, Jaykus L-A: Generation and characterization of nucleic acid aptamers targeting the capsid P domain of a human norovirus GII. 4 strain. J Biotechnol 2015, 209:41-49. 


\section{Highlights}

- Multiplex $\mathrm{q} / \mathrm{dPCR}$ are adequate tools for long-term monitoring

- ICC-qPCR and attachment-based detection enable the rapid assessment of viral infectivity

- $\mathrm{PMA} / \mathrm{EMA} / \mathrm{PtCl}_{4} / \mathrm{CDPP}$ may be used for the detection of potentially infectious viruses

- High throughput sequencing is an excellent tool for investigating emerging viruses

- Biosensors may be used for rapid on-site assessment and monitoring 


\section{Declaration of interests}

$\bigotimes$ The authors declare that they have no known competing financial interests or personal relationships that could have appeared to influence the work reported in this paper.

$\square$ The authors declare the following financial interests/personal relationships which may be considered as potential competing interests: 